\title{
Optimalisasi Kecepatan Belt Conveyor pada Praktikum Time Study di Laboratorium Teknik Perancangan Sistem Kerja
}

\author{
Gemah Delti ${ }^{1}$ \\ 1Politeknik ATI Makassar, Jl. Sunu No. 220 Makassar, email: etti_baq@yahoo.com \\ Submisi: 25 Oktober 2021; Penerimaan: 5 Januari 2021
}

\begin{abstract}
ABSTRAK
Tujuan penelitian ini untuk mengetahui kecepatan optimal belt conveyor pada praktikum time study di laboratorium Teknik Perancangan Sistem Kerja (TPSK) Politeknik ATI Makassar. Lab. TPSK adalah tempat pelaksanaan untuk kegiatan proses pendidikan, baik yang bersifat rutin aktivitas praktikum maupun eksidental berupa suatu tempat yang digunakan untuk percobaan dan pengamatan yang berhubungan dengan bidang ilmu teknik industri. Metode yang digunakan pada penelitian ini yakni metode deskriptif, yakni sebuah metode dengan sasaran untuk menyampaikan gambaran yang sejelas-jelasnya tentang deskripsi time study di Laboratorium TPSK untuk memastikan waktu baku memakai data dan pengukuran waktu maka hasilnya akan dibuat kesimpulan secara umum terhadap optimalisasi kecepatan belt conveyor. Total populasi yang dipakai pada penelitian ini adalah seluruh mahasiswa Teknik Industri Agro yang menjalani perkuliahan praktek pada Laboratorium TPSK jumlah populasi \pm 210 orang mahasiswa. Sampel yang dipakai dalam penelitian ini adalah mahasiswa yang praktek modul time studi sebanyak \pm 93 orang. Hasil pengujian keseragaman data pada percobaan ke dua menggunakan aplikasi miniTab guna menentukan reliability diperoleh 98,9\%. Hasil pengukuran yang dilakukan telah memenuhi syarat $95 \%$ covidence Level dan $5 \%$ Degree of Accuracy dengan bukti $N^{\prime} \leq N$ pada percobaan ke dua dengan kecepatan belt conveyor $1,5 \mathrm{~m} / \mathrm{s}$. Sehingga optimalisasi kecepatan belt conveyor praktikum time study di laboratorium teknik perancangan sistem kerja ada pada kecepatan 1,5 m/s.
\end{abstract}

Kata kunci: optimalisasi; belt conveyor; laboratorium TPSK; Time study dan praktikum.

\section{PENDAHULUAN}

\section{Latar Belakang}

Time study adalah satu metode perhitungan waktu kerja oleh F.W Taylor guna mendapatkan suatu cara kerja yang lebih terbaik. Teknik perhitungan pada time study yakni dua cara yaitu, pengukuran langsung dan pengukuran tak langsung. Yang pertama adalah pengukuran langsung dikarenakan pengukurannya dikerjakan secara langsung yakni tempat dimana kegiatan tersebut dilaksanakan. Yang tercantum pada pengukuran langsung adalah menghitung waktu kerja menggunakan stopwatch dan contoh pekerjaan. Lain halnya pada pengukuran tak langsung dukerjakan dengan cara menghitung tidak harus berada di tempat kerja yakni dengan memperhitungkan data pada tabel data yang tersedia sekiranya memahami cara kerjanya melalui elemen gerakan atau elemen pekerjaan. Yang termasuk kelompok ini adalah data waktu baku dan data waktu gerakan. Dari salah satu metode ini, waktu penanganan suatu pekerjaan yang diupayakan dengan suatu sistem kerja tertentu bisa ditentukan. Sehingga jika pengukuran dilakukan pada beberapa pilihan sistem kerja, yang lebih baik dilihat dari segi waktu dapat dicari adalah sistem yang menggunakan waktu penyelesaian perkerjaan tercepat (Sutalaksana,2006). 
Pengukuran waktu difokuskan
juga untuk memperoleh waktu baku/standar dalam penyelesaian pekerjaan yakni waktu yang digunakan secara normal oleh seorang pekerja wajar untuk menuntaskan suatu pekerjaan yang dilaksanakan dengan cara kerja terbaik. Hal ini bertujuan untuk membuktikan bahwa waktu baku/waktu standar yang diperoleh bukanlah waktu penanganan pekerjaan yang diselesaikan secara tidak normal contoh terlalu lambat atau terlalu cepat, bukan yang dituntaskan oleh pekerja yang luar biasa terampilnya atau pemalas dan lamban, dan tidak pula yang mengerjakannya dengan sistem kerja kategori yang belum unggul. (Sutalaksana, 1979)

Pada aturan Pengukuran Waktu (Time Study) adalah suatu usaha untuk menetapkan lamanya waktu kerja yang dibutuhkan oleh seorang operator untuk mengerjakan suatu pekerjaan/kegiatan yang khusus, kecepatan kerja yang wajar serta pada erea / tempat kerja yang terbaik saat ini. Pengukuran Waktu (Time Study) adalah suatu proses kuantitatif yang ditujukan untuk mendapatkan suatu kriteria yang objektif. (Yanto, Ngaliman, 2017).

Pada mulanya, perhitungan waktu banyak digunakan untuk menghitung insentif (bonus) bagi karyawan. Dalam pengembangannya, pengukuran waktu kerja dapat difungsikan lebih lanjut untuk Melaksanakan penjadwalan dan perencanaan kerja, Menetapkan besaran biaya produksi, menetapkan kuantitas / kebutuhan operator, dan sebagainya

Belt conveyor merupakan alat utama kegiatan praktikum time study, yang merupakan objek utama penelitian ini. Sehingga penulis mengangkat judul penelitian "Optimalisasi Kecepatan Belt conveyor Pada Praktikum Time Study Di Laboratorium Teknik Perancangan Sistem Kerja".

\section{Rumusan masalah}

Rumusan masalah dalam

penelitian ini adalah :

1. Apakah selama ini belt conveyor pada praktikum time study sudah beroperasional dengan baik/optimal?

2. Bagaimana upaya memanfaatkan hasil penelitian ini menjadi tolak ukur penilaian hasil praktek mahasiswa?

\section{Tujuan Penelitian}

Tujuan dilakukannya penelitian ini yaitu memahami data waktu pada aktivitas kerja. Mengetahui waktu baku dari satu aktivitas kerja. Mengetahui kecepatan optimal belt conveyor pada praktikum time study pada lab. TPSK di Politeknik ATI Makassar.

Hasil kegiatan penelitian diharapkan untuk dapat menjadi sumber informasi bagi PLP saat melakukan evaluasi kinerja alat dan bermanfaat untuk pengelola laboratorium Teknik Perancangan Sistem Kerja dalam upaya memanfaatkan hasil penelitian ini menjadi tolak ukur penilaian hasil praktek mahasiswa/i jurusan Teknik Industri Agro (TIA) di Politeknik ATI Makassar.

\section{TINJAUAN PUSTAKA}

\section{Laboratorium}

Laboratorium dipakai menjadi tempat peningkatan pendidikan dan keahlian mahasiswa pada kegiatan perkuliahan praktek. Laboratorium adalah sebuah infrastruktur perkuliahan yang bisa dipakai sebagai sarana untuk melatih mahasiswa untuk memahami konsep dan meningkatkan keahlian saat melakukan percobaan keilmuan.

Laboratorium merupakan tempat beberapa orang yang melaksanakan berbagai macam aktivitas penelitian /riset, pelatihan, pengamatan dan pengujian keilmuan sebagai pendekatan antara ilmu teori dan praktek dari 
berbagai jenis pengetahuan (disiplin ilmu). Secara fisiknya laboratorium dapat juga menyatakan pada satu ruangan tertutup, kamar atau ruangan terbuka. (kutipan jurnal amna emda, 2014)

Aktivitas praktikum maupun aktivitas laboratorium yang diartikan disini yakni kemahiran belajar yang mengharuskan peserta didik berinteraksi dengan bahan sampai pada observasi fakta. Kemahiran menggali ilmu yang dibuat boleh jadi mempunyai jenjang struktur yang berlainan dan ditetapkan oleh tenaga pengajar atau modul panduan kegiatan praktikum. Boleh jadi juga pengalamannya meliputi tahap perencanaan dan perancangan, studi dan defenisi beserta aplikasinya contoh halnya tahap saat terjadinya kegiatan. Aktivitas laboratorium bisa dilaksanakan oleh peserta didik baik secara perorangan maupun grup kecil dan deskripsi ini tidak tergolong demonstrasi grup besar, datang ke museum atau aktivitas luar ruangan. Artinya laboratoium merupakan pusat pendidikan sains seperti ditunjukkan oleh Gambar 1.

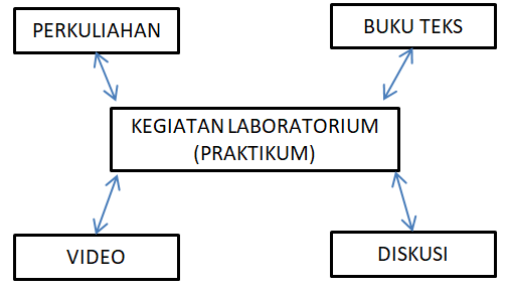

Gambar 1. Peranan Laboratorium

Time Simdey study adalah satu cara pengukuran kegiatan waktu operasi yang dijabarkan oleh F.W Taylor unutk mendapatkan suatu system kerja yang lebih baik. Metode pengukuran pada time study terdapat dua cara yakni: (Rahdiana,2020)

1. Teknik pengukuran langusng, yaitu pengukuran waktu kerja yang dilakukan melalui penelitian. kedua metode yang digunakan dalam teknik langusung ialah

pengambilan Sampel Kerja.
Terkait materi yang akan
dipraktekkan ialah teknik
$\begin{aligned} & \text { pengukuran langusung dengan } \\ & \text { waktu jeda. }\end{aligned}$

2. Cara pengukuran tak langusung, yaitu pengkuran waktu kerja yang dikerjakan melalui pendekatan tabulasi waktu baku yang telah ada (dibuat sebelumnya), atau waktu baku dari pendekatan gerakan-gerakan dasar seperti faktor pekerjaan.

Lain halnya dengan prinsisp ekonomi gerakan merupakan kegiatan menyimulasikan gerakan tubuh saat beraktifitas/bekerja bersumber pada material dan alat yang dipakai. Juga kekurangan manusia pada umumnya. Hal ini amat terkait dengan tata letak fasilitas tempat kerja dan perlengkapan kerja. Pada perancangan kerja secara manual perlu dilaksanakan pengaturan peran kerja bagian tubuh lain contohnya tangan atau keseimbangan muatan tangan kanan dan kiri. Proses ini umumnya digambarkan pada Peta Kerja tangan Kiri dan kanan. (Muh Basri dkk, 2016).

Langkah langkah dalam melakukan perhitungan Time Study antara lain : Menghitung harga rata-rata dari harga rata-rata subgroup, Menghitung standar deviasi sebenarnya dari waktu penyelesaian, Menghitung standar deviasi dari distribusi harga ratarata sub grup dan Menentukan batas kontrol atas dan batas kontrol bawah. Proses tersebut dilakukan dengan cara meninput data pada aplikasi MiniTab.

Langkah selanjutnya melakukan test kecukupan data $5 \%$ dengan Persamaan 1 dan $10 \%$ dengan Persamaan 2. Uji kecukupan data Ketelitian 5\%, untuk memenuhi persyaratan $95 \%$ tingkat keyakinan data valid. Dan Uji kecukupan data Ketelitian $10 \%$, untuk memenuhi persyaratan $90 \%$ 
tingkat keyakinan data valid. Syarat hasil $N^{\prime} \leq N$.

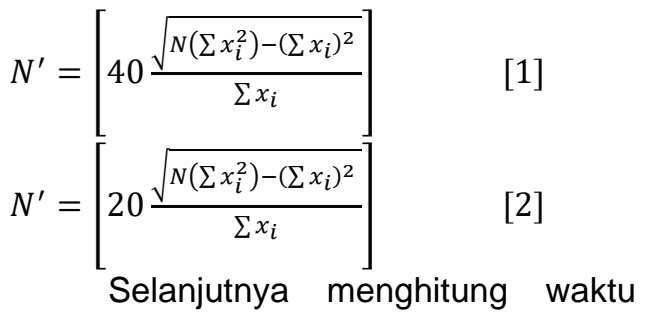
siklus, Menghitung waktu normal dan Menghitung waktu baku (waktu standar) dengan memperhitungkan penyesuaian dan kelonggaran saat bekerja. Dalam time study harus dikerjakan pengukuran penyesuaian dan kelonggaran. Penyesuaian ini difokuskan untuk mengamati kewajaran pekerja saat beraktivitas pada saat dilaksanakan pengukuran waktu kerja. Sebagian cara saat menentukan faktor penyesuaian yakni Cara Presentase, Cara Shumard, Cara Westinghouse, Cara Objektif dan Cara Bedaux dan Sintesa. Tapi yang umum digunakan adalah metode Shumard dan metode objektif. Kelongaran diperbolehkan untuk tiga hal yakni untuk keperluan pribadi, menghilangkan rasa lelah dan kendalakendala yang tak terhindarkan. Semua ini menggambarkan hal-hal yang sangat nyata diperlukan oleh pekerja dan selama pengukuran tidak terpantau saat diukur, dicatat serta dihitung. Persamaan untuk menghitung waktu siklus, waktu normal, dan waktu baku ditunjukkan pada Persamaan 3, Persamaan 4, dan Persamaan 5, secara berurutan(Sutalaksana, 2006).

$W_{s}=\frac{\sum x_{i}}{N}$
$W_{N}=W_{s} \times P$
$W_{B}=W_{N}+\left(i \times W_{N}\right)$

Keterangan:

$\mathrm{P}=$ Faktor penyesuaian

$\mathrm{i}=$ kelonggaran

\section{Belt conveyor}

Belt Conveyor merupakan alat pengangkutan yang cukup simpel yang dipakai untuk mengangkut bahan padat dengan daya muat besar yang terdiri atas belt yang kuat terhadap pengangkutan bahan tersebut [M. Hasriyono, 2009.].

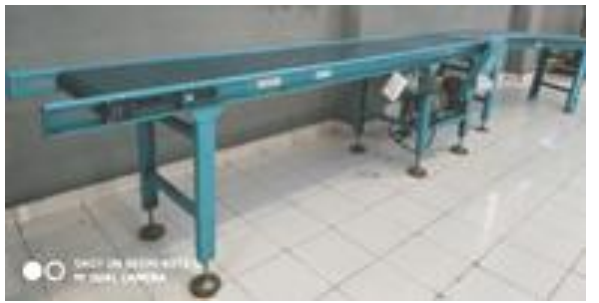

Gambar 2. Belt Conveyor Laboratorium TPSK

Belt conveyor mempunyai elemen utama berupa sabuk yang diposisikan di atas roller penopang. Sabuk dioperasionalkan oleh dinamo melalui suatu katrol, sabuk berputar secara translasi yang melintas datar atau miring terserah kepada kebutuhan dan perencanaan. Bahan material diposisikan tepat diatas sabuk lalu beriringan sabuk bergerak kesatu arah. Untuk proses pengoperasian konveyor sabuk digunakan tenaga penggerak berbentuk motor listrik beserta roda gigi yang dikopel otomatis ke puli motor. Sabuk yang terhubung diatas roller akan berputar melintasi roller dengan irama sesuai dengan putaran dan puli motor. Belt conveyor termasuk peralatan transportasi (conveyor), yakni alat yang digunakan untuk memindahkan barang / bahan curah (banyak partikel, homogen) baik muatan satuan maupun kontinyu (Farid Mujayyin \& Handi Rahmanuri, 2018).

\section{Optimalisasi}

Optimalisasi merupakan hasil yang telah diperoleh sesuai dengan harapan, jadi optimalisasi adalah pencapaian suatu hasil sesuai keinginan secara efisien dan efektif. Dari Kamus Besar Bahasa Indonesia optimalisasi bersumber dari kata optimal yang berarti terbaik, tertinggi. ( Krisna Amelia Yuniar,2017) 
Ada tiga elemen permasalahan optimalisasi yang harus diidentifikasi, yaitu tujuan, alternatif keputusan, dan sumberdaya yang dibatasi.( Krisna Amelia Yuniar,2017)

\section{METODOLOGI PENELITIAN}

\section{Tempat dan Waktu}

Penelitian ini dilaksanakan selama \pm 5 (lima) bulan mulai bulan Februari $\mathrm{s} / \mathrm{d}$ July tahun 2021. Tempat dilaksanakan penelitian di Laboratorium TPSK Politeknik ATI Makassar JI. Sunu No. 220 Sulawesi Selatan. Laboratorium Teknik Perancangan Sistem Kerja (TPSK) merupakan sarana dan prasarana pendukung proses belajar mengajar, baik yang bersifat rutinitas kegiatan praktikum maupun eksidental berupa suatu tempat yang digunakan untuk percobaan dan pengamatan yang

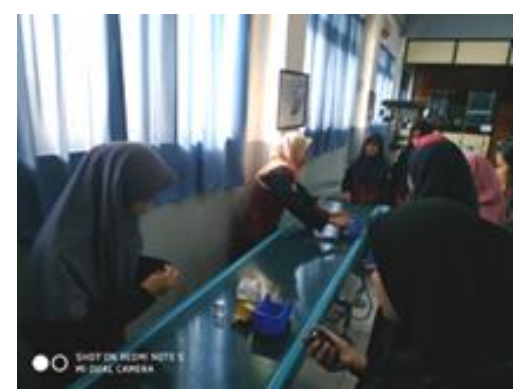

Gambar 3. Praktikum time studi perakitan rautan pensil (data primer, 2020)

\section{Alat dan Bahan Penelitian}

Alat serta Bahan yang dipergunakan untuk kegiatan penelitian dan mengerjakan data penelitian ini terdiri dari : Printer, Kertas HVS A4, Pulpen, Tinta printer, Laptop, Cleaning kit camera, Adapter kamera canon, Kain lap kotak / Kanebo, Baterai stopwatch, WD-40, Baterai kamera canon EOS 700, Dinamo belt conveyor, Transistor inverter beltconveyor, Memory micro card $16 \mathrm{~GB}$, Tang, Stopwatch, Rautan Pensil (Produk), Box produk, Belt Conveyor, Work Station, Software Microsoft Excel dan Microsoft Word, Aplikasi SPSS, Aplikasi miniTab, Flashdisk, Kamera, berhubungan dengan bidang ilmu teknik industry (Gemah delti, 2019).

Pada laboratorium ini melayani kegiatan praktikum mata kuliah praktek TPSK dan praktek Ergonomi. Praktek TPSK dilaksanakan pada semester 3 (Tiga) dan praktek ergonomi pada semester 4 (empat). Mahasiswa yang mengikuti praktek TPSK akan menyelesaikan 3 modul yakni Modul Peta kerja, Modul Motion Study dan Modul Time Study.

Pada modul time studi kegiatan praktikum ada 3 cara yaitu pengukuran waktu kerja cara normal, pengukuran waktu kerja cara fatique dan pengukuran waktu kerja dengan alat belt conveyor. Penelitian ini fokus pada cara yang ketiga, untuk mengetahui optimalisasi alat tersebut. Berikut ini gambar kegiatan praktikum.

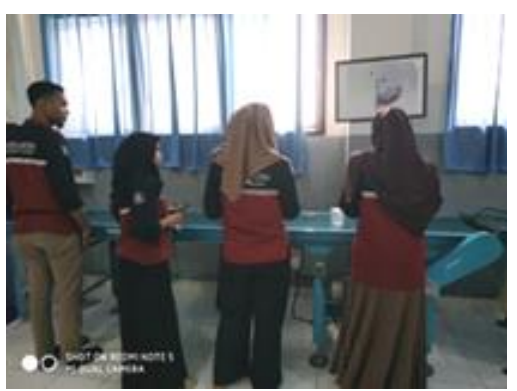

Blanko pengumpulan data, Laporan sementara mahasiswa/lembar pengamatan, Mahasiswa sebagai praktikan dan PLP sebagai peneliti,

\section{Jenis Penelitian}

prosedur yang digunakan dalam penelitian ini yakni cara deskriptif, yakni satu metode yang bertujuan untuk menyampaikan gambaran yang sejelas-jelasnya terkait narasi time study di Lab. TPSK untuk memperoleh waktu baku lewat data dan pengukuran waktu lalu hasilnya akan dibuat keputusan secara umum terhadap optimalisasi kecepatan belt conveyor. 


\section{Data Penelitian}

Data yang didapatkan dan dikumpulkan untuk penelitian ini berasal dari data primer dan data sekunder. Adapun data primer merupakan data yang didapatkan secara langsung saat pengukuran waktu dengan stopwatch dari tiap komponen kerja dan observasi langsung terhadap objek yang diteliti. Dan data sekunder merupakan data yang didapatkan dari sumber tak langsung yakni berupa catatan/dokumen laboratorium ataupun acuan yang relevan pada objek yang sementara diteliti.

\section{Pelaksanaan Penelitian}

Pengumpulan data yang diperlukan pada penelitian ini diperoleh dengan cara :

1. Observasi Lapangan

Salah satu kegiatan yang dilaksanakan dengan melakukan pengamatan secara langsung terhadap kegiatan praktikum, kemudian dicatat guna mendapatkan data yang digunakan dalam penelitian.

2. Dokumentasi

Dilakukan dengan pengumpulan data dan mempelajari dokumendokumen laporan mahasiswa sejak tahun 2015 hingga penelitian ini dilakukan yang berhubungan terhadap objek yang akan diteliti.

3. Pengukuran

Pengukuran pada penelitian ini dilakukan pada:

a) Pengukuran waktu kerja dengan stopwatch dari tiap elemenelemen kerja pada praktikum time Saat akan menetapkan waktu baku / waktu standar maka kita harus menetapkan berapa allowance study perakitan rautan pesil dengan alat belt conveyor.

b) Pengamatan langsung pada saat praktikum.

c) Pengolahan data menggunakan aplikasi untuk hasil lebih akurat.

\section{Kerangka Pikir}

Penelitian ini dilaksanakan di Lab.

TPSK Politeknik ATI Makassar khususnya pada modul time studi dibagian perakitan rautan pensil dengan alat belt conveyor. Persiapan dalam melakukan penelitian yang digunakan adalah mempersiapkan perlengkapan dalam mengerjakan penelitian tersebut terdiri dari penyediaan stopwatch, papan observasi dan alat tulis guna merekam informasi yang dibutuhkan. Pemilihan operator dibutuhkan pada tahap persiapan ini. (Umi Tri Widiawati, 2009)

Penelitian time study dilanjutkan pada kegiatan merekam data yang dibutuhkan terhadap jenis praktikum yang dipilih, yakni praktikum time studi perakitan rautan pensil dengan alat belt conveyor kemudian membagi kegiatan ke beberapa langkah kerja. Observasi dan pengukuran dilakukan sesudah membagi kegiatan praktikum menjadi urutan kerja dan menentukan rating performance pekerja.

Pengukuran jika sudah dilakukan (N) lalu diuji keseragaman data dan uji kecukupan data guna mendapati jumlah pengukuran yang wajib dilakukan ( $\left.\mathrm{N}^{\prime}\right)$, jika data telah cukup dilanjutkan dengan menghitung waktu siklus, waktu normal dan waktu baku. (Muh Basri dkk, 2016)

(kelonggaran) kemudian menghitung rating performance pekerja, kerangka pemikiran ini bisa dilihat di Gambar 4. 


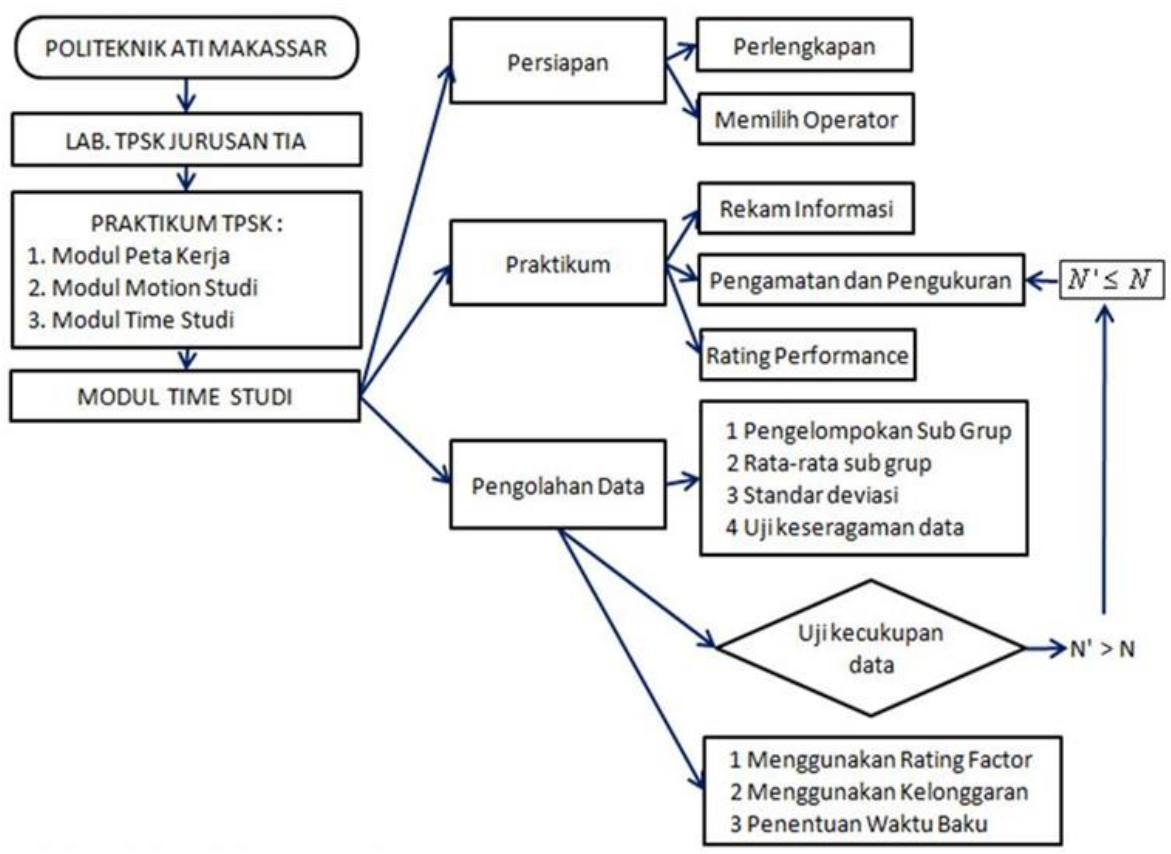

Gambar 4. Kerangka Pikir

\section{HASIL DAN PEMBAHASAN}

Mekanisme praktikum ini di lakukan di laboraturium menggunakan Belt conveyor. Praktikum ini wajib di jalankan oleh para mahasiswa tanpa pengawasan langsung oleh dosen. Sehingga hasil praktikum masih kurang efektif karena tidak ada data acuan. Diharapkan hasil dari kegiatan penelitian ini dapat menjadi tolak ukur penilaian hasil praktek mahasiswa oleh dosen/PLP/Asisten laboratorium. Selain itu Hasil kegiatan penelitian ini juga diharapkan dapat menjadi sumber informasi bagi PLP saat melakukan evaluasi kinerja alat.

Pengumpulan data dikerjakan bertepatan waktu praktikum dengan melaksanakan pengukuran sejumlah 3 kali percobaan untuk setiap operator pada perakitan produk rautan pensil. Praktikum dimulai jam $08.00 \mathrm{~s} / \mathrm{d} 11.30$ wita dilanjutkan lagi pada jam $13.30 \mathrm{~s} / \mathrm{d}$ 15.30 wita (sesuai jadwal perkuliahan).

Melakukan perhitungan waktu perakitan rautan pensil secara menyeluruh. Ulangi perhitungan waktu perakitan rautan pensil sejumlah tiga kali, dengan menggunakan alat belt conveyor. Operator bekerja di depan belt conveyor merakit 8 komponen rautan pensil hingga selesai 1 produk utuh rautan pensil.

Langkah kerja dari perakitan rautan pensil meliputi perakitan body rautan, bantalan poros, pemutar rautan, as gigi, pisau potong, poros, bak penampung hingga dimasukkan ke dos, sedangkan cara pengambilan data waktu dari langkah kerja mulai merakit hingga produk rautan pensil dimasukkan ke dalam dos menggunakan cara pengukuran waktu berulang-ulang (repetitive timing atau snap back timing) yakni saat waktu yang tampil di panel stopwatch akan selalu dikembalikan ke posisi nol pada tiap akhir langkah kerja yang telah diukur. Selesai pencatatan, lalu tombol ditekan kembali dan segera mengerjakan pengukuran untuk langkah kerja selanjutnya.

Langkah pengolahan data mengerjakan pengujian keseragaman data pada data yang terpakai lalu di plot ke grafik. Bila terdapat data yang diluar 
batas kontrol atas maupun bawah, lalu data itu dibuang dan dilakukan lagi uji keseragaman data. Kondisi ini dikerjakan berulang hingga seluruh data berada pada batas kontrol yang memperlihatkan bahwa data tersebut telah seragam.

Pengujian kecukupan data yang terpakai. Bila data tidak cukup, maka data wajib ditambahkan dengan mengerjakan praktikum lagi hingga data yang perlukan cukup. Hitung Waktu Baku, Waktu Normal, dan Waktu Siklus. Berdasarkan data-data hasil pengukuran dapat dihitung Uji keseragaman data, Uji kecukupan data, waktu siklus, waktu normal serta waktu bakunya.

\section{Praktikum pengukuran waktu dengan kecepatan $2 \mathrm{~m} / \mathrm{s}$.}

Tabel 3 menunjukkan hasil praktikum dengan pengukuran sebanyak 93 pengukuran yang akan di uji keseragaman data menggunakan software minitab dengan hasil seperti pada Gambar 4. Gambar 4a menunjukkan ada beberapa hasil percobaan yang melewati Batas Kontrol Atas (BKA/UCL) yakni data praktikan no $2 ; 3 ; 4 ; 10 ; 33 ; 34 ; 41 ; 64 ; 65 ; 66$, lalu data itu dikeluarkan dan dilakukan lagi uji keseragaman data. Gambar 4b menunjukkan ada beberapa hasil percobaan yang melewati BKA yakni data praktikan no $7 ; 28 ; 83$, maka data itu dikeluarkan dan dilakukan lagi uji keseragaman data. Gambar 4c menunjukkan ada hasil percobaan yang melewati BKA yakni data praktikan no 6 , maka data itu dikeluarkan dan dilakukan lagi uji keseragaman data. Gambar 4d menunjukkan ada beberapa hasil percobaan yang melewati BKA yakni data praktikan no. 26; 54 , lalu data itu dikeluarkan dan dilakukan lagi uji keseragaman data. Berdasarkan Gambar 4e dapat dilihat bahwa tidak ada data yang melewati BKA dan BKB, sehingga data dinyatakan seragam dan dapat dilanjutkan uji kecukupan data. Uji kecukupan data Ketelitian 5\%, demi memenuhi syarat $95 \%$ convidence level. Uji kecukupan data Ketelitian 5\%, untuk memenuhi persyaratan $95 \%$ tingkat keyakinan data valid. Dan Uji kecukupan data Ketelitian $10 \%$, untuk memenuhi persyaratan $90 \%$ tingkat keyakinan data valid. Syarat hasil N' $\leq \mathrm{N}$.

Tabel 3. Pengukuran dengan kecepatan $2 \mathrm{~m} / \mathrm{s}$

\begin{tabular}{cccc}
\hline \multirow{2}{*}{ No } & U1 & $\begin{array}{c}\text { Waktu (detik) } \\
\text { U2 }\end{array}$ & U3 \\
\hline 1 & 45.31 & 55.05 & 43.16 \\
2 & 72 & 71 & 69 \\
3 & 70 & 64 & 69 \\
4 & 57.01 & 46.98 & 57.72 \\
5 & 32.67 & 25.16 & 47.09 \\
6 & 26.91 & 34.2 & 28.2 \\
7 & 24.01 & 22.78 & 27.2 \\
8 & 38.1 & 31.29 & 31.74 \\
9 & 48.2 & 40.85 & 38.47 \\
10 & 63.28 & 59.32 & 45.52 \\
11 & 56.27 & 32.44 & 32.61 \\
12 & 26.43 & 30.5 & 21.35 \\
13 & 28.3 & 37.81 & 22.93 \\
14 & 23.8 & 19.89 & 20.45 \\
15 & 25.04 & 28.87 & 24.54 \\
16 & 24.73 & 33.69 & 20.02 \\
\hline
\end{tabular}

\begin{tabular}{cccc}
\hline \multirow{2}{*}{ No } & \multicolumn{3}{c}{ Waktu (detik) } \\
& U1 & U2 & U3 \\
\hline 17 & 31.95 & 30.91 & 23.14 \\
18 & 21.44 & 22.63 & 41.6 \\
19 & 23.18 & 38.8 & 22.1 \\
20 & 39.03 & 24.29 & 21.51 \\
21 & 24.98 & 21.45 & 27.87 \\
22 & 23.71 & 13.66 & 31 \\
23 & 25.21 & 29.08 & 23.97 \\
24 & 26.74 & 31.34 & 23.42 \\
25 & 29.37 & 30.33 & 33.01 \\
26 & 32.62 & 26.03 & 22.2 \\
27 & 30.81 & 27 & 23.09 \\
28 & 27.29 & 28.25 & 23.4 \\
29 & 26.72 & 28.81 & 24.6 \\
30 & 34.14 & 24.88 & 21.53 \\
31 & 42.26 & 40.92 & 50.1 \\
\hline
\end{tabular}




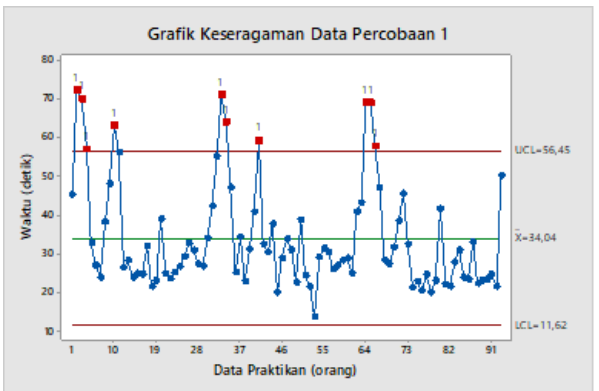

a

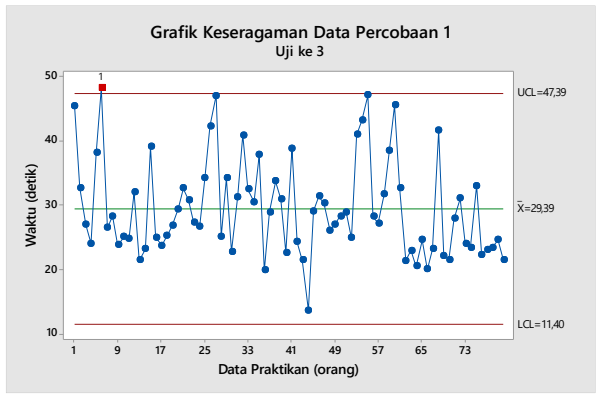

C

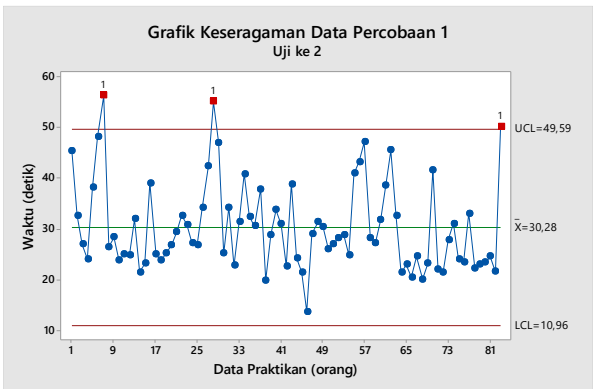

b

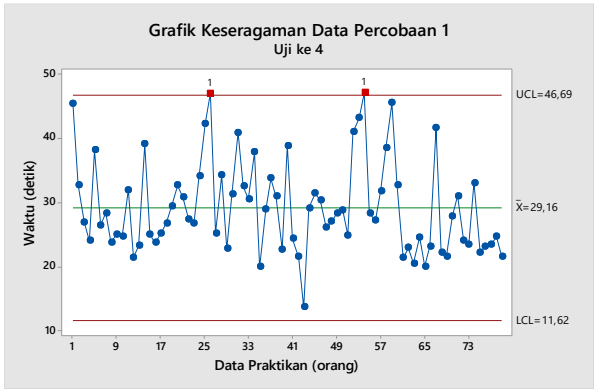

d

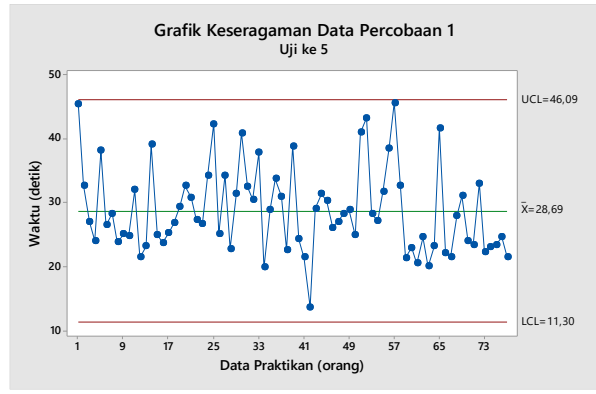

e

Gambar 4. Hasil uji keseragaman data pengukuran waktu dengan kecepatan 2 m/s.

$$
\begin{aligned}
N^{\prime} & =\left[\frac{40 \sqrt{77(66806)-(2209,24)^{2}}}{2209,24}\right]^{2} \\
& =\left[\frac{20520}{2209,24}\right]^{2}=86 \text { pengukuran } \\
& \text { Dari hasil pengolahan data, }
\end{aligned}
$$
diperoleh $\mathrm{N}^{\prime}=86>\mathrm{N}=77$ artinya data diatas tidak cukup. Tidak memenuhi syarat untuk $95 \%$ convidence level. Sehingga dilakukan uji kecukupan data untuk ketelitian $10 \%$ dan $90 \%$ convidence level.

$$
\begin{aligned}
N^{\prime} & =\left[\frac{20 \sqrt{77(66806)-(2209,24)^{2}}}{2209,24}\right]^{2} \\
& =\left[\frac{10260}{2209,24}\right]^{2}=21 \text { pengukuran }
\end{aligned}
$$

Dari hasil pengolahan data, diperoleh $\mathrm{N}^{\prime}=21<\mathrm{N}=77$ artinya data diatas cukup dan memenuhi syarat untuk $90 \%$ convidence level. Sehingga data bisa dilanjutkan untuk hitung waktu siklus, waktu normal dan waktu baku.

\section{Hitung Waktu Siklus (Ws)}

Ws $=\frac{2209,24}{77}=28,7$ detik

Penetapan performance rating menggunakan metode Shumard dan metode objektif untuk dihitung waktu normal Penyesuaian dengan cara Shumard $\left(P_{1}\right)$ dengan nilai operator 75 dan normal 60 , sehingga $P_{1}=1,25$ 


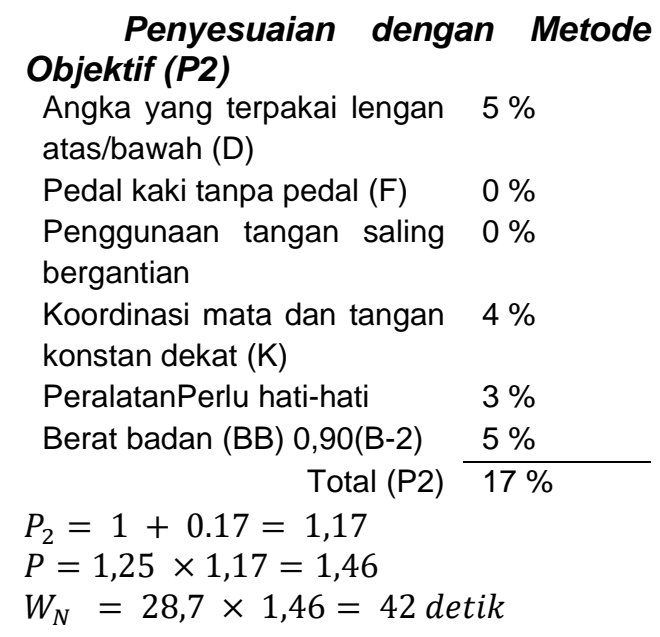

Kelonggaran (Allowence)

Keb. Pribadi $2 \%$

Tak Terhindarkan $\quad 2 \%$

Fatique

Tenaga yang dikeluarkan $\quad 2 \%$

Sikap kerja $\quad 0,5 \%$

Gerakan kerja $\quad 0 \%$

Kelelahan Mata $\quad 6,5 \%$

Temperatur tempat kerja $\quad 2 \%$

Atmosfer $\quad 0 \%$

Lingkungan
Waktu Baku (WB)

$W_{B}=42+15 \%(42)=48,3$ detik

Dari hasil pengolahan data diperoleh $\mathrm{W}_{\mathrm{B}}=48,3$ detik. Artinya waktu standar penyelesaian perakitan rautan pensil oleh praktikan yang wajar pada situasi dan kondisi normal untuk kecepatan belt conveyor $2 \mathrm{~m} / \mathrm{s}$ adalah 48,3 detik.

\section{Praktikum pengukuran waktu dengan kecepatan 1,5 m/s \\ Tabel 5 menunjukkan hasil} praktikum dengan pengukuran sebanyak 93 data yang akan di uji keseragaman data menggunakan software minitab ditunjukkan pada Gambar 5. Gambar 5a menunjukkan ada hasil percobaan yang melewati BKA yakni data no 46, maka data itu dibuang lanjut lagi uji keseragaman data. Dari Gambar 5b dapat dilihat bahwa tidak ada data yang melewati Batas Kontrol Atas (BKA/UCL) dan batas kontrol bawah, sehingga data dinyatakan seragam dan dapat dilanjutkan uji kecukupan data.

Tabel 5. Pengukuran dengan kecepatan $1,5 \mathrm{~m} / \mathrm{s}$

\begin{tabular}{cccc}
\hline No & U1 & $\begin{array}{c}\text { Waktu (detik) } \\
\text { U2 }\end{array}$ & U3 \\
\hline 1 & 29.68 & 38.33 & 39.4 \\
2 & 37 & 37 & 35 \\
3 & 40 & 38 & 36 \\
4 & 44.91 & 44.71 & 40.76 \\
5 & 45 & 22.13 & 32.09 \\
6 & 26.89 & 26.51 & 23.97 \\
7 & 37.7 & 27 & 38 \\
8 & 43.37 & 23.3 & 30.5 \\
9 & 30.92 & 39.17 & 40.99 \\
10 & 42.38 & 36.52 & 39.7 \\
11 & 39.1 & 38.48 & 35.82 \\
12 & 28.55 & 32.11 & 36.06 \\
13 & 29.76 & 26.57 & 22.61 \\
14 & 21.93 & 28.81 & 28.06 \\
15 & 19.5 & 83.45 & 24.72 \\
16 & 34.87 & 23.47 & 29.55 \\
\hline
\end{tabular}

\begin{tabular}{cccc}
\hline \multirow{2}{*}{ No } & \multicolumn{3}{c}{ Waktu (detik) } \\
& U1 & U2 & U3 \\
\hline 17 & 26.03 & 33.01 & 21.44 \\
18 & 21.45 & 31 & 23.71 \\
19 & 22.63 & 27.87 & 24.73 \\
20 & 29.08 & 23.97 & 24.98 \\
21 & 30.33 & 23.42 & 25.21 \\
22 & 30.91 & 23.14 & 26.74 \\
23 & 31.34 & 20.44 & 29.37 \\
24 & 33.69 & 20.02 & 31.95 \\
25 & 26.19 & 38.8 & 20.22 \\
26 & 24.56 & 39.75 & 38.89 \\
27 & 32.8 & 27 & 31.86 \\
28 & 22.8 & 20.4 & 20.95 \\
29 & 29.44 & 45.59 & 38.87 \\
30 & 29.44 & 24.7 & 31.38 \\
31 & 22.88 & 39.4 & 23.75 \\
\hline
\end{tabular}




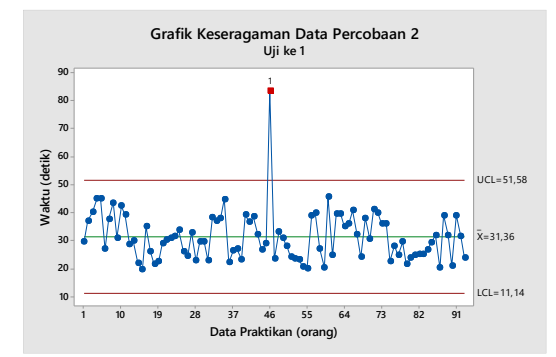

a

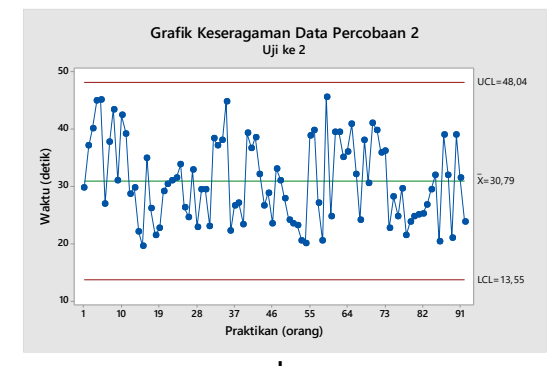

b

Gambar 5. Hasil uji keseragaman data pengukuran waktu dengan kecepatan $1.5 \mathrm{~m} / \mathrm{s}$.

Uji kecukupan data ketelitian 5\%, guna terpenuhi syarat $95 \%$ convidence level.

$$
\begin{aligned}
N^{\prime} & =\left[\frac{40 \sqrt{92(91856)-(2833,03)^{2}}}{2833,03}\right]^{2} \\
& =\left[\frac{26067,2}{2833,03}\right]^{2}=84,6 \text { pengukuran } \\
& \text { Dari hasil pengolahan data, }
\end{aligned}
$$
diperoleh $\mathrm{N}^{\prime}=84,6<\mathrm{N}=92$ artinya data tersebut cukup dan memenuhi syarat untuk $95 \%$ convidence level. Sehingga data bisa dilanjutkan untuk menghitung waktu siklus, waktu normal dan waktu baku.

$$
\begin{gathered}
\text { Hitung Waktu Siklus (Ws) } \\
\text { Ws }=\frac{2833,03}{92}=31 \text { detik } \\
\text { Penetapan performance rating }
\end{gathered}
$$
menggunakan metode Shumard dan metode objektif untuk dihitung waktu normal Penyesuaian dengan cara Shumard $\left(P_{1}\right)$ dengan nilai operator 75 dan normal 60 .

$P_{1}=\frac{75}{60}=1,25$

\section{Objektif (P2)}

Penyesuaian dengan Metode

Nilai total P2 sama seperti pada praktikum dengan kecepatan $2 \mathrm{~m} / \mathrm{s}$ yaitu 0.17 , sehingga :

$P_{2}=1+0.17=1,17$

$P=1,25 \times 1,17=1,46$

$W_{N}=31 \times 1,46=45,3$ detik

Kelonggaran (Allowence)

Nilai kelonggaran sama seperti pada praktikum dengan kecepatan $2 \mathrm{~m} / \mathrm{s}$ yaitu $15 \%$

Waktu Baku (WB)

$W_{B}=45,3+15 \%(45,3)=52$ detik
Dari hasil pengolahan data diperoleh $W_{B}=52$ detik. Artinya waktu standar penyelesaian perakitan rautan pensil oleh praktikan yang wajar pada situasi dan kondisi normal untuk kecepatan belt conveyor $1,5 \mathrm{~m} / \mathrm{s}$ adalah 52 detik.

\section{Praktikum pengukuran waktu dengan kecepatan $1 \mathrm{~m} / \mathrm{s}$ \\ Tabel 6 menunjukkan hasil} praktikum dengan pengukuran sebanyak 93 data yang akan di uji keseragaman data menggunakan software minitab dengan hasil seperti pada Gambar 6 . Dari Gambar 5a dapat dilihat bahwa ada beberapa hasil percobaan yang melewati Batas Kontrol Atas (BKA/UCL) dan BKB yakni data praktikan no $5 ; 8 ; 9 ; 10 ; 37 ; 47$; 90, lalu data itu dikeluarkan dan dilakukan lagi uji keseragaman data. Dari Gambar 5b dapat dilihat bahwa ada beberapa hasil percobaan yang melewati Batas Kontrol Atas (BKA/UCL) yakni data praktikan no $5 ; 31 ; 35 ; 64$, lalu data itu dikeluarkan dan dilakukan lagi uji keseragaman data. Berdasarkan Gambar 5c dapat dilihat bahwa ada beberapa hasil percobaan yang melewati Batas Kontrol Atas (BKA/UCL) yakni data praktikan no 33, lalu data itu dikeluarkan dan dilakukan lagi uji keseragaman data. Berdasarkan Gambar 5d dapat dilihat bahwa tidak ada data yang melewati Batas Kontrol Atas (BKA/UCL) dan batas kontrol bawah, sehingga data dinyatakan seragam dan dapat dilanjutkan uji kecukupan data. 
Tabel 6. Pengukuran dengan kecepatan $1 \mathrm{~m} / \mathrm{s}$

\begin{tabular}{cccc}
\hline No & \multicolumn{3}{c}{ Waktu (detik) } \\
& U1 & U2 & U3 \\
\hline 1 & 32.73 & 34.2 & 33.2 \\
2 & 32 & 36 & 33 \\
3 & 35 & 40 & 36 \\
4 & 33.21 & 43.04 & 30.57 \\
5 & 45.59 & 38.87 & 29.44 \\
6 & 42.55 & 45.1 & 31.69 \\
10 & 44.7 & 41.73 & 38.98 \\
11 & 41.14 & 41.35 & 35.9 \\
12 & 30.12 & 33.77 & 26.84 \\
13 & 24.73 & 33.69 & 20.02 \\
14 & 26.74 & 31.34 & 23.42 \\
15 & 21.44 & 22.63 & 20.44 \\
16 & 23.71 & 13.66 & 31 \\
17 & 24.29 & 21.51 & 30.81 \\
\hline
\end{tabular}

\begin{tabular}{cccc}
\hline \multirow{2}{*}{ No } & \multicolumn{3}{c}{ Waktu (detik) } \\
& U1 & U2 & U3 \\
\hline 18 & 28.81 & 27.8 & 32.62 \\
19 & 26.03 & 22.2 & 26.72 \\
20 & 33.88 & 21.53 & 34.14 \\
21 & 38.89 & 25.62 & 39.03 \\
22 & 24.88 & 24.6 & 27.29 \\
23 & 28.25 & 23.09 & 26.24 \\
24 & 27 & 23.4 & 26.06 \\
25 & 26.63 & 39.75 & 26.19 \\
26 & 19.58 & 26.06 & 24.56 \\
27 & 27.8 & 20.95 & 22.8 \\
28 & 23.35 & 29.31 & 50.79 \\
29 & 24.7 & 31.38 & 29.44 \\
30 & 27 & 31.86 & 32.8 \\
31 & 29.72 & 21.44 & 19.21 \\
\hline
\end{tabular}
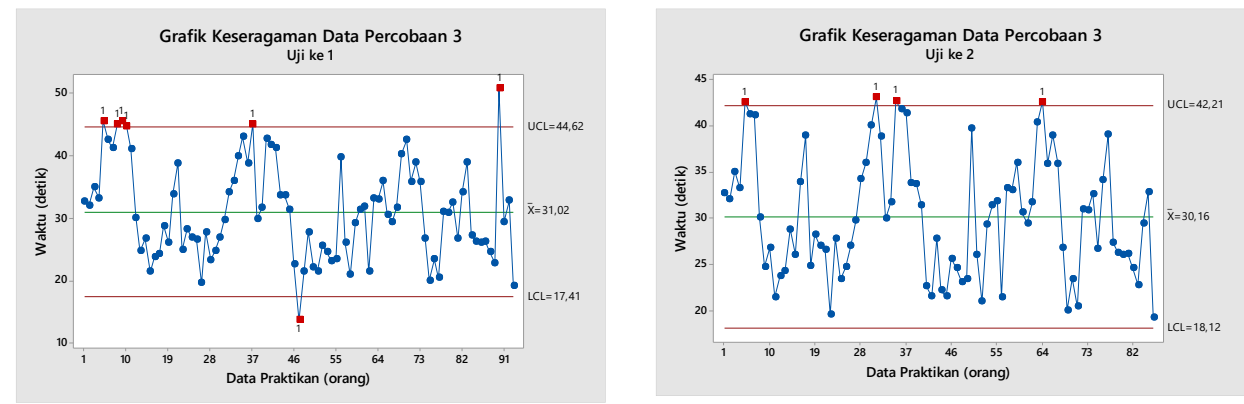

a

Grafik Keseragaman Data Percobaan 3

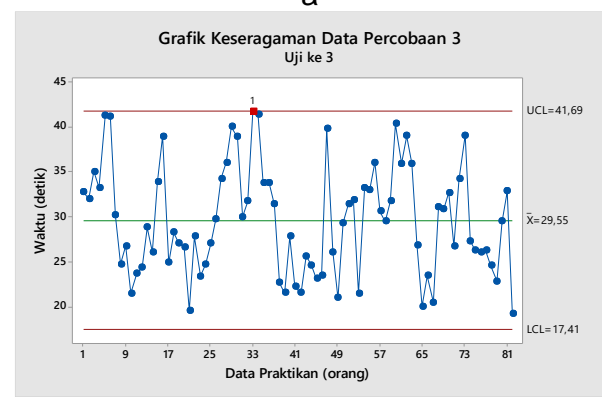

b

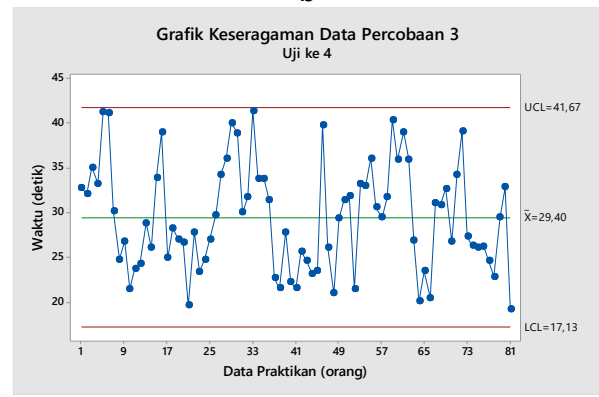

d

Gambar 6. Hasil uji keseragaman data pengukuran waktu dengan kecepatan $1 \mathrm{~m} / \mathrm{s}$

$$
\begin{aligned}
N^{\prime} & =\left[\frac{40 \sqrt{N \sum X i^{2}-\left(\sum X i\right)^{2}}}{\sum X i}\right]^{2} \\
& =\left[\frac{40 \sqrt{81(72827)-(2381,45)^{2}}}{2381,45}\right]^{2}= \\
& {\left[\frac{19086}{2381,45}\right]^{2}=64 \text { pengukuran } }
\end{aligned}
$$

Dari hasil pengolahan data, diperoleh $\mathrm{N}^{\prime}=64<\mathrm{N}=81$ artinya data diatas cukup dan memenuhi syarat untuk $95 \%$ convidence level. Sehingga data bisa dilanjutkan untuk dihitung waktu siklus, waktu normal dan waktu baku.

\section{Waktu Siklus (Ws)}

Ws $=\frac{\Sigma X_{i}}{N}=\frac{2381,45}{81}=29$ detik

Penetapan performance rating menggunakan metode Shumard dan metode objektif untuk dihitung waktu normal Penyesuaian dengan cara Shumard $\left(P_{1}\right)$ dengan nilai operator 75 dan normal 60.

$P_{1}=\frac{75}{60}=1,25$ 


\section{Penyesuaian dengan Metode Objektif (P2)}

Nilai total P2 sama seperti pada praktikum dengan kecepatan $2 \mathrm{~m} / \mathrm{s}$ dan $1,5 \mathrm{~m} / \mathrm{s}$ yaitu 0.17 , sehingga:

$P_{2}=1+17 \%=1,17$

$P=1,25 \times 1,17=1,46$

$W_{N}=29 \times 1,46=42,34$ detik

\section{Kelonggaran (Allowence)}

Nilai kelonggaran sama seperti pada praktikum dengan kecepatan $2 \mathrm{~m} / \mathrm{s}$ dan $1,5 \mathrm{~m} / \mathrm{s}$ yaitu $15 \%$.

Waktu Baku (WB)

$W_{B}=42,34+15 \%(42,34)=$ 48,7 detik

Dari hasil pengolahan data diperoleh $\mathrm{W}_{\mathrm{B}}=48,7$ detik. Artinya waktu standar penyelesaian perakitan rautan pensil oleh praktikan yang wajar pada situasi dan kondisi normal untuk kecepatan belt conveyor $1 \mathrm{~m} / \mathrm{s}$ adalah 48,7 detik.

Setelah melakukan pengolahan data terhadap 3 percobaan tersebut diatas, maka dapat dilihat pada tabel 7 . Optimalisasi Kecepatan Belt conveyor Praktikum Time Studi Di Laboratorium Teknik Perancangan Sistem Kerja ada pada kecepatan $1,5 \mathrm{~m} / \mathrm{s}$ (pada percobaan ke 2). Hal tersebut ditetapkan karena tingkat keyakinan data valid $95 \%$ dan nilai reliability data tertinggi.

Tabel 7. Optimalisasi Kecepatan Belt conveyor Praktikum Time Studi

\begin{tabular}{|c|c|c|c|c|c|c|}
\hline \multirow[b]{2}{*}{ No } & \multirow[b]{2}{*}{$\begin{array}{l}\text { Kecepatan } \\
(\mathrm{m} / \mathrm{s})\end{array}$} & \multicolumn{3}{|c|}{ Percobaan / Praktikum } & \multicolumn{2}{|l|}{ Keterangan } \\
\hline & & $\begin{array}{l}\text { Waktu } \\
\text { Siklus } \\
\text { (detik) }\end{array}$ & $\begin{array}{l}\text { Waktu } \\
\text { Normal } \\
\text { (detik) }\end{array}$ & $\begin{array}{l}\text { Waktu } \\
\text { Baku } \\
\text { (detik) }\end{array}$ & $\begin{array}{l}\text { Reliability } \\
\text { (Keandalan) }\end{array}$ & $\begin{array}{l}\text { Convidence } \\
\text { Level (Tingkat } \\
\text { kepercayaan) }\end{array}$ \\
\hline 1 & 2 & 28,7 & 42 & 48,3 & $82,8 \%$ & $90 \%$ \\
\hline 2 & 1,5 & 31 & 45,3 & 52 & $98,9 \%$ & $95 \%$ \\
\hline 3 & 1 & 29 & 42,34 & 48,7 & $87,1 \%$ & $95 \%$ \\
\hline
\end{tabular}

Time study adalah salah satu metode yang dipakai guna menetapkan waktu baku dari setiap pekerjaan yang dilakukan hingga diperoleh langkah kerja dan rangkaian kerja yang terbaik, besarnya hasil yang diperoleh dan waktu yang diperlukan untuk menuntaskan tiap langkah kerja. Karena adanya pengukuran yang dikerjakan, maka dapat diketahui nilai waktu baku dalam penyelesaian praktikum perakitan rautan pensil.

Dari penerapan uji time study pada penelitian perakitan rautan pensil dengan alat belt conveyor kita dapat mengetahui data waktu suatu aktivitas kerja yaitu Ws $=31$ detik dan $W n=45,3$ detik, mengetahui waktu baku dari suatu aktivitas kerja $\mathrm{Wb}=52$ detik dan mengetahui kecepatan optimal beltconveyor praktikum time studi pada lab.TPSK di Politeknik ATI Makassar yakni kecepatan $1,5 \mathrm{~m} / \mathrm{s}$.

\section{KESIMPULAN DAN SARAN}

\section{Kesimpulan}

Berdasarkan hasil pembahasan tersebut diatas, maka dapat diambil sebuah kesimpulan sebagai berikut:

1. Hasil pengujian keseragaman data pada percobaan ke dua dengan kecepatan belt conveyor $1,5 \mathrm{~m} / \mathrm{s}$ menggunakan aplikasi miniTab guna menentukan reliability diperoleh 98,9 \%. Pengujian kecukupan data juga dilakukan dan sudah memenuhi persyaratan $95 \%$ covidence Level dan $5 \%$ Degree of Accuracy yang dibuktikan N' $\leq$ N. Ini membuktikan bahwa selama ini belt conveyor pada praktikum time study sudah beroperasional dengan baik/optimal. 
2. Waktu baku dari penelitian praktikum time studi perakitan rautan pensil dengan alat belt conveyor adalah sebesar 52 detik untuk 1 siklus 1 produk rautan pensil, waktu ini meliputi langkah kerja menyusun 8 komponen ke dalam dos. Data tersebut akan menjadi tolak ukur penilaian hasil praktek mahasiswa. Jika laporan hasil praktek mahasiswa jauh dari angka tersebut, maka wajib melakukan praktikum ulang karena diindikasi adanya kekeliruan saat praktikum.

Data tersebut juga menjadi sumber informasi bagi PLP saat melakukan evaluasi kinerja alat dan bermanfaat untuk pengelola laboratorium. Sehingga optimalisasi kecepatan belt conveyor praktikum time studi di laboratorium teknik perancangan sistem kerja ada pada kecepatan 1,5 $\mathrm{m} / \mathrm{s}$.

\section{Saran}

1. Diharapkan penelitian terkait uji time studi yang lebih akurat sebab penelitian ini masih bersifat penelitian pendahuluan.

2. Dilakukan evaluasi dan monitoring terhadap hasil praktikum mahasiswa khususnya pada praktikum time studi dengan alat belt conveyor, jika data yang diperoleh diluar dari hasil penelitian ini.

\section{DAFTAR PUSTAKA}

Amna Emda, 2014. Lantanida Journal, Vol. 2 No. 2, Banda Aceh
Farid Mujayyin \& Handi Rahmanuri, 2018. Diagnosa Kerusakan Belt Conveyor Coal Storage Pabrik Semen Gresik Menggunakan Metode Visual Monitoring dan Pemeriksaan Geometris, Gresik

Gemah Delti, 2019. Pengelolaan dan Pelayanan praktikum di Lab TPSK, Integrated Lab Journal Vol. 07, No. 02. Yogyakarta

Krisna Amelia Yuniar, 2017. Optimalisasi Pengelolaan Zakat dan Efektifitas Amil Zakat terhadap Peningkatan Perolehan Zakat, Infak, Sedekah (ZIS) di Badan Amil Zakat Nasional (BAZNAS) Tulungagung, (Tulungagung: Skripsi Tidak Diteritkan), hal. 17

M. Hasriyono, 2009. Evaluasi efektifitas mesin dengan penerapan total productive maintenance (TPM) di PT Hadi Baru, Tugas Akhir, Universitas Sumatera Utara, Medan

Muh basri dkk, 2016. Modul praktikum lab TPSK - Time Studi, Makassar

Rahdiana, N.dkk (2020). Analisis Perancangan Sistem Kerja. Karawang

Sutalaksana, I.Z., Anggawisastra, R., Tjakraatmadja, J.H., (1979). Teknik Tata Cata Kerja. Penerbit ITB. Bandung

Sutalaksana, I.Z., Anggawisastra, R., Tjakraatmadja, J.H., (2006). Teknik Perancangan Sistem Kerja. Penerbit ITB. Bandung

Umi Tri Widiawati, 2009. Deskripsi time and motion study untuk mengetahui waktu baku di produksi sambal PT. Heinz ABC Indonesia Karawang, Surakarta

Yanto, Ngaliman, B., (2017). Ergonomi, Dasar-dasar Studi Waktu dan Gerakan untuk Analisis \& Perbaikan Sistem Kerja. Penerbit C.V. Andi Offset. Yogyakarya. 